\title{
Microanalytical study of luster glazed gilding and silvering from Baroque altarpieces
}

Nati Salvadó ${ }^{*}$, Salvador Butí1 ${ }^{1}$, Carme Clemente $^{2}$, Victòria Beltran ${ }^{1 \S}$, Gianfelice Cinque ${ }^{3}$, Jordi Juanhuix ${ }^{4}$, and Trinitat Pradell ${ }^{5}$.

1. Dpt. d'Enginyeria Química. EPSEVG. Universitat Politècnica de Catalunya, Av. Víctor Balaguer s/n, 08800 Vilanova i la Geltrú, Barcelona

2. Escola d'Art i Disseny de la Diputació de Tarragona a Tortosa, Pl. Sant Joan, 5, 43500 Tortosa

3. Diamond Light Source, Harwell Campus, Chilton-Didcot OX11 0DE Oxfordshire, UK

4. CELLS-ALBA Synchrotron, Carrer de la Llum 2-26, 08290 Cerdanyola del Vallès, Barcelona

5. Dpt. Física and BRCMSE, Universitat Politècnica de Catalunya, Campus del Baix Llobregat. c) Esteve Terradas 8, 08860 Castelldefels, Barcelona

*Corresponding author: E-mail address: nativitat.salvado@upc.edu

${ }^{\S}$ Current adress: IPANEMA, CNRS MC UVSQ MNHN, Université Paris-Saclay, BP48 Saint-Aubin, 91192 Gifsur-Yvette cedex, France

Keywords: microFTIR, microXRD, cultural heritage, gilding, silvering, bole, Pinus resin, sandarac, silver corrosion, verdigris, red lake

\section{ABSTRACT}

Lustering, a technique which involved the application of coloured translucent glazes over gilding and silvering was widely used to enrich and decorate altarpieces in the Baroque period. The decorations consist of a micrometric multilayered structure including several color glazes, metallic leaves and bole applied over a plaster ground. The collection of Baroque altarpieces, the oldest dating 1671 and the newest 1775 from the cathedral of Tortosa (Catalonia), is a perfect case of study of the materials used and the techniques employed throughout the period. Further information is obtained from the analysis of the reaction and aging compounds resulting from the interaction among the compounds present in the layers and between the different layers.

A combination of sensitive analytical techniques, Synchrotron based $\mu$-XRD and $\mu$-IR and SEM-EDS which enabled the luster samples to undergo analysis without altering their original layered microstructure were selected. The nature of the compounds used to produce the yellow, green, red and blue glazes (pigments, pigment lakes and resins), metallic leaves and boles is presented. Relevant information from historical and conservation viewpoints about the origin and nature of the materials used, the making of the lusters and their reactivity and aging are also discussed.

\section{INTRODUCTION}

Innovations in art works are very often related to the discovery of new materials or techniques. Therefore, the analysis of the materials gives direct information about the materials available in the period, the use of synthetic and natural products and in each case the procedures used to obtain or to purify them. However, the materials change over the years due to the reactivity and aging of the substances and what reaches us is the result of these changes. Therefore, the current appearance of the art work is often very different from the appearance it had at the time of its creation. The investigation of the nature and changes happening in an artwork is often a complex analytical problem, which requires different analytical methods 
and specific sample preparation methods.

Coloured translucent glazes over gilding and silvering, also known as lustering, were used in altarpieces as a low cost method for imitating gold, gemstones, glazes, vitreous enamels and luxurious cloths and for the addition of interesting shiny effects and different shades depending on the artist criteria. The technique consisted in the application of a thin (20-50 microns) colour glaze over metal silver, gold, brass or occasionally, tin [1-6]. The colour is obtained adding dyes, pigments or lake pigments, in variable amounts, into an organic matrix. Consequently, organic and inorganic substances either crystalline or amorphous coexist in the glazes. Chemical interactions among the different substances present in a luster glazed over gold or silver, as well as, with the environment (atmospheric gases, dust, polluting gases, humidity, etc) resulted in the change of the chemistry and also of the physical properties of the layers. The consequent reduction of the brilliancy and transparency of the organic glaze gives gilded and silvered decorations a dull aspect. Furthermore, subsequent restorations often introduce other materials not always adequate to ensure their preservation. All this yields a complex material [5-7] that requires a specific set of complementary microanalytical techniques.

While in the 17th Century the Gothic tradition was still present in terms of materials used and the method of application, the Baroque period comprised between the second half of the 17th century and the end of the18th century, is a time of important changes by the introduction of new materials and techniques. Lustering was, geographically and chronologically gradually introduced in Baroque altarpieces [8] and in particular widely used in the Mediterranean basin. The oldest coloured glazes were generally made of drying oil and applied to small motifs. At the end of the 17th Century resin based glazes started being used to cover more extensive areas. Resins from different natural sources as indicated by the treatises of the period were used. Different dyes, lake pigments and pigments to resin proportion were used to produce different chromatic effects.

The coloured lustering of a set of seven Baroque altarpieces created between 1671 and 1776 from the Cathedral of Tortosa in Catalonia are studied. The altarpieces have been kept in place for over 300 years and, consequently, submitted to the same environmental conditions. This circumstance also facilitates a comparative study of the reactivity of the materials from the period. Tortosa is a city located a short distance from the mouth of the River Ebre, which, in the studied period, connected the Iberian Peninsula with the Mediterranean trade and so, open to all the technical and artistic European influences. Consequently, the set of Baroque altarpieces from the Cathedral of Tortosa constitutes a perfect case to study the reactivity and aging, as well as, the evolution of the materials and techniques.

Analytical techniques with adequate detection limits, limited invasiveness and, especially, without altering the original microstructure of the layers must be considered. The microstructure of the sample (thickness, number of layers, particles, etc.) are determined by Optical Microscopy (OM) and Scanning Electron Microscopy (SEM). Elemental analysis may also be obtained either by Energy Dispersive X-ray Spectroscopy EDS attached to the SEM or, X-ray Fluorescence. With regard to the identification of the nature of the compounds present Micro Infrared Spectroscopy ( $\mu$-FTIR), Micro Raman Spectroscopy ( $\mu$-Raman) and Micro X-ray Diffraction ( $\mu$-XRD) are among the most commonly employed. The use of synchrotron radiation (SR) adds micro-focusing capability and high quality data due to the brightness and high signal to noise ratio and may be critical for the success of the analysis [9-12]. 


\section{EXPERIMENTAL}

\section{Samples and sample preparation}

Artwork samples. 37 samples a few hundred micrometres in size were taken from the seven Baroque altarpieces, spanning a period of one hundred years, located at the cathedral of Tortosa. A selection of the samples belonging to four of these altarpieces dedicated to All Souls (2 samples), Saint Joachim (11 samples), Saint Rufus (10 samples) and Our Lady of the Rosary (6 samples) (in chronological order) are discussed here and summarised in Table 1.

Cross sections. Polished cross sections and thin cross sections of the samples were obtained for analysis $[10,11]$. Small fragments of the samples (a few hundred micrometers in size) were first embedded in epoxy resin and subsequently microtomed. In some samples, a thin gold protection layer was applied on the surface before embedding the sample to avoid the contamination of the sample by the epoxy resin [11]. $2 \mu \mathrm{m}$ and $20 \mu \mathrm{m}$ thick cross sections were cut for the infrared and X-ray diffraction measurements respectively. The $2 \mu \mathrm{m}$ thin cross sections were pressed between two $\mathrm{KBr}$ pellets transparent to the IR to assure their flatness and assist in handling. Also, a few $150 \mu \mathrm{m}$ cross section cuts obtained with a precise diamond saw were also prepared for X-ray diffraction measurements.

Moreover, selected sample fragments were squeezed between two diamond windows into a microcompression cell to obtain samples of adequate thickness for the IR analysis. The various materials present in the sample were spread facilitating the analysis of the different substances and, at the same time, maintaining the layered structure of the paint.

\section{Methods and instrumentation}

The combination of various micro sensitive analytical techniques including Synchrotron based $\mu-X R D$, and $\mu-I R$ in combination with SEM has proved to be a powerful tool to obtain precise information on the composition and distribution of the reaction and aging substances in a sequence of micrometric layers, such as is the case with luster glazed gilding and silvering (glaze, metal leaf, bole and ground layers).

\section{Optical microscopy (OM)}

The samples were observed, handled and small fragments selected for further analysis by means of a Stereomicroscope, SMZ800 Nikon. The cross-sections of the samples were observed with an Optical microscope Eclipse LV100 Nikon under visible and UV light.

\section{Scanning Electron Microscopy with energy dispersive x-ray spectroscopy (SEM-EDS)}

SEM-EDS was used in order to obtain information of the elemental composition and thickness of the layers of the samples. Secondary electron (SE) and backscattered electron (BSE) images were acquired with a GEMINI SEM equipped with a Shottky-FE column (4pA$20 \mathrm{nA}, 0.1$ to $30 \mathrm{kV}$ and $1 \mathrm{~nm}$ maximum resolution) at an accelerating voltage of $20 \mathrm{kV}$. Elemental analysis was also obtained by Energy Dispersive X-ray Spectrometry (EDS) using an INCAR Penta FETX3 detector and a $30 \mathrm{~mm}^{2}$ ATW2 window attached to the Electron Microscope. The EDS spectrometer is calibrated using mineral standards which ensure quantitative analysis of polished surfaces. The samples, small fragments and cross-sections, were carbon coated to ensure the electrical conductivity.

\section{Synchrotron-based infrared microspectroscopy ( $\mu$ SR-FTIR)}


IR analysis provides molecular specificity and structural information of the different compounds present in the paint layers. A high spectral quality (signal/noise ratio) at the highest spatial resolution (diffraction limited) can be achieved thanks to the high brilliance and collimation of synchrotron radiation. Synchrotron based FTIR allows work to be carried out in confocal mode conveniently between 5 to 15 microns; i.e. accessing the true micron scale which is important to reveal both the chemical species and spatial distribution, with no compromise on the low wavenumber spectral range (an effect typical when closing slits with benchtop). Thus, $\mu$ SR-FTIR is particularly useful due to its capability of mapping on a micrometric scale.

The set up used included a Hyperion 3000 IR microscope, a broad-band high sensitivity MCT detector and a 36x condenser coupled to the Vertex 80v interferometer available at the end station of beamline MIRIAM B22 at Diamond Light Source, UK [13]. The spectra were obtained in transmission mode using a small beam spot of $15 \times 15 / 12 \times 12$ square microns, 4 $\mathrm{cm}^{-1}$ resolution, co-adding 256 scans at scanner velocity $80 \mathrm{kHz}(35 \mathrm{sec})$, in the 4000 to 650 $\mathrm{cm}^{-1}$ wavenumber range. Molecular composition IR maps were obtained by scanning the sample via a micrometric resolution motorized $\mathrm{X}-\mathrm{Y}$ stage.

\section{Synchrotron-based $X$-ray diffraction ( $\mathrm{HSR}$-XRD)}

Taking into account that many substances are present, in each layer, often in very low amount, $\mu \mathrm{SR}-\mathrm{XRD}$ was used to resolve the complex mixtures of crystalline compounds present in this micrometric layered samples. $\mu$ SR-XRD data was obtained at XALOC beamline at ALBA Synchrotron, Cerdanyola del Vallès (Barcelona) [14]. A 50×6 $\mu \mathrm{m}^{2}$ (width $\times$ height FWHM) focused beam with an energy of $11.800 \mathrm{keV}(1.0507 \AA$ wavelength $)$ was used to collect a series of diffraction patterns from either 20 or $150 \mu \mathrm{m}$ thick cross-sections of the samples; the cross sections were scanned vertically at steps of 3 microns allowing some overlapping. Typical acquisition times varied between 0.2 to $1 \mathrm{~s}$ using a virtually noise free Pilatus 6M (Dectris) detector with a large active area $\left(424 \times 435 \mathrm{~mm}^{2}, 6\right.$ Mpixels $)$ protected by a small beam stop. The powder diffraction patterns of the layers were obtained by radial integration of the images obtained by this two-dimensional detector. This setup provides a high sensitivity to poor diffracting compounds present in very low amounts and a large 2theta range.

Chemical and mineral compound identification was carried out by comparison with large databases from The International Centre for Diffraction Data, The RRUFF database and published data.

\section{RESULTS AND DISCUSSION}

The colour glazed over gold and silver leaves are constituted by a sequence of layers including a coloured coating, metal leaf, bole and a ground layer. The ground layers, applied on a wooden support, are basically made of gypsum and anhydrite (gesso grosso) mixed with a protein binder (animal glue). Above this ground, one or more layers of bole were applied. The bole is, essentially, a fine clay with protein binder which, thanks to the colloidal size of its constituents and high plasticity, facilitates the adherence and burnishing of the metal leaves. The Baroque period the main technique used is gilding and silvering on bole.

\section{Gold and silver leaves}

Gold or silver are the most common metal leaves employed in these altarpieces. Small amounts of silver $(<1 \%-7 \%)$ and also, in some cases of copper $(1 \%-2 \%)$ are found in the gold 
leaves whereas the silver leaf used was of high purity (copper is not detected by SEM-EDS). The thickness of the metal leaves varies between 0.12 and $0.35 \mu \mathrm{m}$ and between 0.15 and 0.50 $\mu \mathrm{m}$ for the gold and silver leaves respectively. These very thin leaves were obtained by the conventional beating technique which profits from the high ductility of gold and silver. The metal leaves were applied over a bole layer and burnished with an agate stone.

Coloured glazes were applied to confer to the gold and silver leaves a glowing effect and enhance their brightness (Figures 1a and 2a). Moreover, in the case of the silver leaves, the glaze also had a protective function; to prevent the formation of silver sulfide, $\operatorname{Ag}_{2} \mathrm{~S},[15]$ and silver chloride, $\mathrm{AgCl}$ [16-19] (Figure 1b). The glaze avoids the reaction of the metallic silver with the oxygen from the environment to produce silver oxides, $\mathrm{Ag}_{2} \mathrm{O}[19,20]$ which is required to finally form silver sulfide and chloride. $\mathrm{Ag}_{2} \mathrm{~S}$ is obtained from the reaction with pollutant gases, such as, hydrogen sulphide $\left(\mathrm{H}_{2} \mathrm{~S}\right)$ and carbonyl sulphide (OCS) [21,22], while $\mathrm{AgCl}$ with the chloride ions present in atmospheric sea spray, which together with the humidity penetrate through the porosity of the protected layer [21]. Nevertheless, chlorine can also be present in very small amounts in the binding media and adhesives; in fact, we have stated that the analysis of several rabbit glues showed the presence of $\mathrm{Cl}$ associated to impurities.

The results obtained demonstrate that atmospheric corrosion is the prevailing alteration mechanism and, therefore, the alteration of the metal leaves is mainly related to the conservation state of the protective coatings. Figure 1a shows a detail of the elaborate silvering work with yellow glaze details from the altar frontal of the Saint Joachim's altarpiece. All the silvered area was protected by a proteinaceous substance layer according to contemporary Treatises[1], over which, the yellow glazes details were applied. In fact, silver appears mainly unaltered and only small amounts of $\mathrm{Cl}$ are determined by SEM-EDS (Figure 1b) in those yellow areas where two coating layers cover the silver foil (currently, three layers, the most external varnish layer was added in a modern restoration, 1997). On the contrary, those areas where the yellow glaze and proteinaceous layer are missing (Figure 1c), a continuous layer of acanthite (the monoclinic $\mathrm{Ag}_{2} \mathrm{~S}$ ) is formed, Figure 1e bottom, although a very small amount of $\mathrm{Cl}$ is also determined by SEM-EDS. These corrosion layers may be very thick, up to $1 \mu \mathrm{m}$, and even in the case shown, $2 \mu \mathrm{m}$. Acanthite gives a characteristic black-tarnish appearance at a macroscopic level. In fact, it is possible that some of the areas were kept uncoated on purpose to obtain it. If the coatings are partially lost, metallic silver and acanthite are mainly determined (Figure 1d, e top).

On the other hand, $\mathrm{AgCl}$ chlorargyrite is always found in the inner areas of protected silver leaves. However, higher amounts of $\mathrm{AgCl}$ are determined in those leaves protected by a single coating than in those protected by several coating layers (Figure 1). Moreover, in the cases where the coating layer contains pigment particles or cracks, the amount of $\mathrm{AgCl}$ is even higher (Figure 2). In fact, this alteration process may end up with the complete transformation of silver into silver chloride [21]. Moreover, the penetration of the atmosphere through cracks and pores boost the growth of silver corrosion products which may cause tensions and flaking of the glazing.

As a consequence of all this, there is a large variability in the state of conservation of the silver leaves even in the same altarpiece.

\section{Bole}

The bole is made of an iron oxide rich clay mixed with a proteinaceous substance which 
assists the adherence of the metal leaf. Three different boles showing different colours, red, red-violet and ochre are identified in the set of altarpieces. The colour of bole also contributes to the final colour shown by the luster gilded and silvered areas. Red boles were widely used in the Gothic and Renaissance periods. In fact, in the set of altarpieces studied here the red bole is found only in one altarpiece dating from the beginning of the 18th century. The redviolet bole was introduced approaching the 18th century and was gradually replaced in the last third of the 18th century by the ochre bole. Both, the red-violet and the ochre coloured boles may be related to local sources and historical documentation supports the exploitation of local boles in Tortosa. However, to ascertain this further study is needed. The thickness of the bole layer varies between 10 and $20 \mu \mathrm{m}$ and, sometimes two or more layers are superimposed reaching a thickness between 40 and $80 \mu \mathrm{m}$. The complex mixture of minerals present in the boles is determined by $\mu$-XRD [23, 24]. And due to the micrometric thickness of the internal layers, in many cases the use of this technique associated with synchrotron radiation is clearly advantageous. A cross section of the sample is mounted on a goniometer; although this setup accurately positions the selected area in the x-ray beam it forbids rotation. This method has some limitations: the microcrystallites are not necessarily isotropically oriented and consequently some texturing effects related to preferred crystalline orientations which may be favoured by the method of application of the paint layers may happen. Moreover, the small beam spot size limits the size of the crystallites that may be measured without giving individual crystal diffraction spots. Thus, the relative intensity of the diffracted peaks may not completely agree with the powder diffraction pattern. Figure $\mathbf{3}$ shows a representative image of the diffraction rings corresponding to the clay minerals present in a bole layer showing a layered orientation.

The $\mu$ SR-XRD patterns of the three boles, corresponding to red, red-violet and yellow, obtained from thin cross-sections of the samples are shown in Figure 3. The red bole (Figure 3a) composition contains a dioctahedral mica of muscovite type, $\mathrm{KAl}_{2} \mathrm{Si}_{3} \mathrm{AlO}_{10}(\mathrm{OH})_{2}$, hematite, $\mathrm{Fe}_{2} \mathrm{O}_{3}$, and quartz, $\mathrm{SiO}_{2}$. The red/violet bole (Figure $3 \mathbf{b}$ ) contains a Mg-chlorite -clinochlore $\left(\mathrm{Mg}_{5} \mathrm{Al}\right)(\mathrm{Si}, \mathrm{Al})_{4} \mathrm{O}_{10}(\mathrm{OH})_{8}-$, a dioctahedral mica of muscovite type $\mathrm{KAl}_{2} \mathrm{Si}_{3} \mathrm{AlO}_{10}(\mathrm{OH})_{2}$, hematite $\mathrm{Fe}_{2} \mathrm{O}_{3}$ and quartz $\mathrm{SiO}_{2}$. Finally, the yellow bole (Figure 3c) contains dioctahedral mica, muscovite type, $\mathrm{KAl}_{2} \mathrm{Si}_{3} \mathrm{AlO}_{10}(\mathrm{OH})_{2}$, kaolinite, $\mathrm{Al}_{2} \mathrm{Si}_{2} \mathrm{O}_{5}(\mathrm{OH})_{4}$, goethite, $\mathrm{FeO}(\mathrm{OH})$, a potassium feldspar, $\mathrm{KAlSi}_{3} \mathrm{O}_{8}$, quartz, $\mathrm{SiO}_{2}$, and calcite, $\mathrm{CaCO}_{3}$. The presence of a small amount of calcium carbonate, in the yellow bole can come from the natural source rock. Calcium oxalate dehydrate $\mathrm{CaC}_{2} \mathrm{O}_{4} \cdot 2 \mathrm{H}_{2} \mathrm{O}$, weddellite was also determined in the bole layers.

Although the analysis of clays by infrared spectroscopy is difficult due to the strong overlap of bands from the different compounds, the micrometric resolution and high quality infrared spectra obtained by $\mu$ SR-FTIR helps the discrimination of the phyllosilicates from other materials. Figure 4a shows a SR-FTIR spectrum of a red-violet bole. The infrared absorption bands present at the $4000-3000 \mathrm{~cm}^{-1}$ spectral region belong to the stretching vibration of structural hydroxyl groups and to the stretching vibration of water. The $\mathrm{OH}$-stretching band near $3620 \mathrm{~cm}^{-1}$ can be assigned to muscovite or illite and those at about $3560 \mathrm{~cm}^{-1}$ to $\mathrm{Mg}$ chlorite [25, 26, RRUFF ID:R060725.1]. Besides the phyllosilicates the presence of protein related to animal glue is also determined (Figure 4). The broad stretching band at $3400 \mathrm{~cm}^{-1}$ may be related to the $\mathrm{H}_{2} \mathrm{O}$ stretching vibration from the absorbed water of Mg-chlorite distorted by the overlapping of the $3300 \mathrm{~cm}^{-1}$ band of N-H stretching vibrations from the amide group of protein and of the $\mathrm{O}-\mathrm{H}$ stretching vibrations of water molecules.

Animal glue was extensively used in Europe in the period both as a binder and as adhesive for 
the metal leaf. Baroque treatises recommend the use of rabbit glue because of its good adhesive properties in bole gilding and silvering [1,27]. Animal glue is constituted mainly of collagen but the identification of the animal species to which the collagen belongs needs more specific proteomic studies [28]. One particularly interesting result obtained is the correlation observed between the protein the bole layer and calcium oxalates. The presence of protein decreases (black line in Figure $\mathbf{4 b}$ ) while calcium oxalate increases (red line in Figure $\mathbf{4 b}$ ) in those areas close to the ground layers which contain calcium. Figure $\mathbf{4 b}$ shows that the amide I band at $1650 \mathrm{~cm}^{-1}$ shifts towards lower wavenumbers approaching $1620 \mathrm{~cm}^{-1}$ where the $\mathrm{C}-\mathrm{O}$ stretching vibration of coordinated oxalate groups appear. Moreover, the intensity of the amide II band around $1540 \mathrm{~cm}^{-1}$ decreases while other bands characteristic of calcium oxalate, $1320 \mathrm{~cm}^{-1}$ and $780 \mathrm{~cm}^{-1}$, increase. Consequently, this data denotes that the presence of calcium oxalate in the inner layers is an indicator of the presence of altered organic matter [29]. This is indeed the case, as calcium oxalate is also found in the ground layers.

\section{Coloured glazes}

Drying oils are determined in the $17^{\text {th }}$ century coloured glazes from the Cathedral of Tortosa whereas resins are identified in the $18^{\text {th }}$ century lusters. Diterpenic resins, particularly, the abietane-type resin from the Pinus species is the main resin applied in the $18^{\text {th }}$ century altarpieces. However, in some cases, mixtures of Pinus resin with drying oil or other resin types such as sandarac (diterpenic resin) or shellac (sesquiterpenic resin) are also used. For instance, a mixture of Pinus resin and sandarac is found in all the coloured glazes from both the altar frontal and the main body of Saint Joachim`s altarpiece. The use of glazes made of sandarac and Pinus resin are also described in historical sources.

The yellow glazed silvering from Figure 1a was analysed by $\mu$ SR-FTIR. The coating shows a sequence of three micrometric layers applied over the silver leaf. The composition and thickness of the layers is clearly shown in the IR maps corresponding to the integration of selected bands related to the protein (Figure 5a, layer I), the mixed resin (Figure 5b, layer II) and the acrylic resin (Figure 5c, layer III) are plotted. Above the silver leaf there is a first 5 to $10 \mu \mathrm{m}$ thick protein rich layer followed by a $20-30 \mu \mathrm{m}$ resins mixture covered by a $<5$ $\mu \mathrm{m}$ top layer of synthetic acrylic resin and which is related to an intervention performed twenty years ago.

The second layer is a mixture of Pinus and sandarac resins (black line in Figure 5d). Pinus resins (colophony) are mainly made up of two types of diterpenoids, i.e., compounds with abietane or pimarane skeletons. During Pinus resin aging, oxidative processes and molecular changes happen. Resins of different Pinus species evolve into a similar molecular composition consisting in oxidized abietanes and high molecular weight compounds. In Figure 5d the infrared spectrum characteristic fingerprint from aged Pinus resin is shown (orange line) [30,31]. The IR spectrum presents a complex shape where the specific markers of aged Pinus resin can be identified. However, the bands at 1647, 1033 and $890 \mathrm{~cm}^{-1}$ in the $1800-700 \mathrm{~cm}^{-1}$ region (Figure 5d) do not belong to the aged Pinus resin but are related to sandarac, a labdane-type resin obtained from Tetraclinis articulate Vahl.

As mentioned, sandarac is also a diterpenic resin whose main compound is the polymerized communic acid. The structure of communic acid is very similar to those of abietic acid, the main compound of the fresh Pinus resin, sharing some IR bands (Figure 5d) such as those at around $1695 \mathrm{~cm}^{-1}$ corresponding to $-\mathrm{COOH}$, which has almost the same chemical environment. However, some differences are still appreciated such as the presence of the conjugated $\mathrm{C}=\mathrm{C}$ band at about $1645 \mathrm{~cm}^{-1}$ in the sandarac spectrum (Figure 5d, green line). 
Although the composition of sandarac also changes upon aging due to oxidation processes, the characteristic bands at 1647,1033 and $890 \mathrm{~cm}^{-1}$ of the fresh resin are still present in aged samples (Figure 5d). Confirmation of the presence of Pinus resin and sandarac in the second layer of the glaze is clearly seen comparing the spectrum with those resulting from the addition of a moderately oxidized resin, aged Pinus nigra Arnold resin from 1884 (Economic Botany Collection of Kew, ref. 28172), and an aged sandarac resin from 1953 (Economic Botany Collection of Kew, ref. 95431) (Figure 5d, red dashed line). The presence of Pinus resin and sandarac has also been confirmed by GC/MS.

An analytical problem presents itself when substances related to the origin and/or synthesis of the pigments are present in the resin matrix. For instance, the lake pigments used in the red glazes also contain reaction compounds associated to the auxiliary substances used in its synthesis. The cross section of the red glaze from the Saint Rufus altarpiece shows a $<30 \mu \mathrm{m}$ thick deep red colour layer containing a Pinus resin matrix and a red lake pigment, Figure 6a. Three different substances are determined by $\mu$ SR-FTIR; the Pinus resin associated to the matrix (Figure 6b and 6c, orange line), starch grains which were typically added as a pigment extender [32] (Figure 6b and 6c, grey line) and protein related to a red lake pigment (Figure 6b and 6c, dark red line). The origin of protein it is not clear, but there are various reasonable hypotheses. One possibility is that the red lake might be recovered either from a wool textile or wool shearing waste [33]. Another possible origin is related to the probable source of the red dye; a product extracted from an insect of the superfamily Coccoidea (scale insects of the order Hemiptera) [34]. Finally, it may also be related to the proteinaceous binders (glue or egg white) added to aid the lake precipitation [32] or mixed and ground together with the lake pigments before included in the resin.

Moreover, the infrared bands doublet at $1079 \mathrm{~cm}^{-1}$ and $1044 \mathrm{~cm}^{-1}$ (Figure 6c) may be indicative of the presence of carminic acid (a hydroxyanthraquinone compound) related to an insect red dye, cochineal carmine. Carminic acid is the main component of all cochineal dyes from various species. However, to confirm liquid chromatography-mass spectrometry based techniques [35] or surface-enhanced Raman spectroscopy [36,37] are adequate to identify a specific red lake.

Aluminium was the main element found by SEM-EDS in the red particles (Figure 6d). Other elements, such as calcium, potassium, sulphur, chlorine, phosphorus, and silicon are also detected in varying amounts (Figure 6d). Aluminium and calcium are associated to the metaldye complex as they form insoluble complexes with the dye molecules via coordinated bonds. The analysis of the particles suggests the presence of an Al-dye complex as main component and a Ca-Al-dye which cannot be completely ruled out in lesser amount. Moreover, particles containing aluminium, sulphur and potassium or sulphur and potassium only, are also determined. They might be related to the impurities resulting from the synthesis of the red dye; in fact, alum, a potassium aluminium sulphate hydroxide hydrate, $\mathrm{KAl}\left(\mathrm{SO}_{4}\right)_{2} \cdot 12 \mathrm{H}_{2} \mathrm{O}$ was commonly used to precipitate the lakes [34] and, in the process by-products such as, potassium sulphate could be generated.

Another source of difficulties in the characterisation of the coloured glazes is the possible interactions between the pigments, lake pigments and dyes with the resin matrix. An interesting example of this is found in the green glaze from the Saint Rufus altarpiece. Copper acetate monohydrate, $\mathrm{Cu}\left(\mathrm{CH}_{3} \mathrm{COO}\right)_{2} \cdot \mathrm{H}_{2} \mathrm{O}$, basic copper acetate with the formula $\mathrm{Cu}\left(\mathrm{CH}_{3} \mathrm{COO}\right)_{2}\left[\mathrm{Cu}(\mathrm{OH})_{2}\right]_{3} \cdot 2 \mathrm{H}_{2} \mathrm{O}$ and also copper hydrochloride, $\mathrm{Cu}_{2} \mathrm{Cl}(\mathrm{OH})_{3}$ are determined 
by $\mu$ SR-XRD Figure 7a. The use of copper acetate/basic copper acetate (verdigris) for green shades was common in the Baroque period [38,39], and so it is in the set of altarpieces we studied. Towards the end of the period the introduction of new pigments in the market resulted in the generation of a new green/blue colour obtained mixing Prussian blue with the yellowish resin. In fact, in some the altarpieces decorated after the first quarter of the $18^{\text {th }}$ century (Saint Joachim, Saint Joseph and Our lady of the Rosary), the presence of Prussian blue is determined.

The synthesis of the green copper pigment usually produces mixtures of various compounds of the type $\left[\mathrm{Cu}\left(\mathrm{CH}_{3} \mathrm{COO}\right)_{2}\right]_{x}\left[\mathrm{Cu}(\mathrm{OH})_{2}\right]_{\mathrm{y}} \cdot \mathrm{nH}_{2} \mathrm{O}$, those compounds can react with the atmosphere producing other compounds, in particular copper chloride salts of the type $\left[\mathrm{CuCl}_{2}\right]_{x}\left[\mathrm{Cu}(\mathrm{OH})_{2}\right]_{y} \cdot \mathrm{nH}_{2} \mathrm{O}[9,39]$. Although copper chloride salts may also be produced during the synthesis of the pigment itself as a result of the addition of sodium chloride, this was more common in medieval pigments according to the recipes described in the manuscripts than in the Baroque period. In fact, SEM observation of the green glaze from the Saint Rufus altarpiece shows that the copper chloride particles are concentrated near the surface suggesting that in this case their presence is related to weathering. Moreover, the $\mu$ SR-XRD pattern (Figure 7a) of the green glaze also shows the presence of other crystalline phases which have not been identified, but which might be related to the reaction between the copper pigment and the Pinus resin.

The abietic acid and abietane skeleton acids from the Pinus resin react with the copper compounds producing copper abietates (copper carboxylate) [7,38,39]. According to the treatises, the green glazes were a green translucent material which suggests that most of the pigment particles had already reacted before application and thus, abietic acid and abietane skeleton acids would have almost reacted completely. In fact, by varying the copper pigment to resin ratio different optical effects were achieved. A non-embedded thin cross section of the green glaze layer, obtained cutting the sample with a microknife and squeezing it on a diamond cell, was measured by $\mu$ SR-FTIR and spectra are shown in Figure $7 \mathbf{b}$. The main characteristic infrared bands related to the green copper pigment and to copper abietates are observed. The intense band at $1608 \mathrm{~cm}^{-1}$ corresponds to the antisymmetric stretching of the $\mathrm{COO}^{-}$group of copper carboxylates formed from abietic acid and abietane skeleton acids. This band overlaps the 1606-1608 $\mathrm{cm}^{-1} \mathrm{C}=\mathrm{C}$ stretching band from the aged Pinus resin [30]. Moreover, the band at about $1400 \mathrm{~cm}^{-1}$ can be associated to the symmetric stretching of the $\mathrm{COO}^{-}$group of the copper abietate. The $885 \mathrm{~cm}^{-1}$ band is also related to this compound [7].

The $\mathrm{C}=\mathrm{O}$ stretching band of the $-\mathrm{COOH}$ from the resin is observed at a higher wavenumber, $1708 \mathrm{~cm}^{-1}$ (Figure 7b), than in the fresh Pinus resin. This is due to the presence of ketones in the aged resin. Due to the fact that the resin has reacted almost completely with the copper pigment, this band appears with low intensity. This facilitate distinguish other bands, such as the band observed at about $1670 \mathrm{~cm}^{-1}$ in the green glaze (Figure $7 \mathbf{b}$ ) which can be associated to $\mathrm{C}=\mathrm{C}$ stretching of $\mathrm{R}_{2} \mathrm{C}=\mathrm{CH}$ of pimarane diterpenoid compounds [31]. In addition, the band observed at $1301 \mathrm{~cm}^{-1}$ (Figure $7 \mathbf{b}$ ) could be attributed to the $=\mathrm{CH}$ rocking of $\mathrm{C}=\mathrm{C}$ terminal also present in pimarane diterpenoid compounds. In fact, fresh Mediterranean Pinus resin species contain pimaranes and non-oxidized abietanes in a ratio of $1: 2$ to $1: 3$ [40-46]. The interaction between the copper pigment and the pimaranes from the resin is also expected, although there are no references of this phenomenon.

And finally, IR spectra of the green glaze (Figure 7b) also shows the $1542 \mathrm{~cm}^{-1}$ symmetric stretching of the $\mathrm{COO}^{-}$group band [47] associated with calcium abietates. With regard to the 
origin of the calcium we have to mention that $\mathrm{CaCO}_{3}$ particles related to environmental deposition are occasionally found on the surface of the glaze. This, together with the reaction and aging compounds formed and the alteration of the metallic leaves has modified the appearance of the lusters to a darkened, matt aspect.

\section{CONCLUSIONS}

Luster glazed gilts and silvering from a set of Baroque altarpieces dating from the last quarter of the $17^{\text {th }}$ century and $18^{\text {th }}$ century from the Cathedral of Tortosa were studied. Limited invasiveness was considered and, for this a selection of representative submilimetric samples were obtained from the altarpieces. The strategy of combining a set of microanalytical techniques which enabled the analysis without altering the original layered microstructure of the samples was fundamental to gain information on the substances related to the original materials used and the reactions among them and between the different layers (glazes, metallic leaves, boles and ground).

The resin matrix used in the coloured glazes, reaction and aging compounds, impurities related to the synthesis of pigments, pigment lakes and dyes, the metallic leaves (gold and silver), the silver corrosion products and the boles were identified. The glazes were made of a, probably local, diterpenic resin (Pinus resin, colophony) which was used alone or mixed with imported sandarac or drying oil. Three different color boles, probably of local origin, were chronologically used, red, red-violet and yellow. The phyllosilicates (muscovite, magnesium chlorite, kaolinite) and iron oxides (goethite and hematite) constituting each of the three different boles were determined. The colourants and pigment particles appear always associated with other substances used either in their synthesis or formed by the reaction with the resin. For instance, the carmine red lake pigment appears associated to auxiliary substances used in its synthesis (starch, aluminium potassium sulphates and related byproducts). Whereas the basic copper acetate green pigment appears together with the copper abietates resulting from its reaction with the Pinus resin matrix. Different silver corrosion products (silver chloride and silver sulphide) are formed depending on the presence or absence of a protective coating. Reactivity is not confined within the luster layers but on the contrary, the reaction between bole and ground layer (calcium oxalates).

\section{Acknowledgements:}

The project received financial support from MINECO (Spain), grant MAT2016-77753- R and Generalitat de Catalunya, grant 2014SGR-581. We acknowledge Diamond Light Source for time on Beamline MIRIAM B22 under Proposal (SM8153/ SM12570) and the collaboration of Diamond staff. The $\mu$ SR-XRD experiments were performed at BL13 XALOC beamline at ALBA Synchrotron Facillity with the collaboration of ALBA staff. The authors thank the "Economic Botany Collection of the Royal Botanic Gardens, Kew", in Richmond (Greater London, UK), for supplying dated ancient resins.

We especially thank the chapter of the Saint Mary of Tortosa Cathedral to allow the access to the altarpieces.

\section{References}

1. F.V. Orellana. Tratado de Barnices y Charoles, (Joseph Garcia, ed.), València (1785). 
2. S. K. Kroustallis. Diccionario de Materias y Técnicas. I. Materias, (Ministerio de Cultura, ed.), Madrid (2008).

3. J. Tauber. Polychrome Sculpture, The Getty Conservation Institute, Los Angeles (2015).

4. I.C.A. Sandu, L.U. Alfonso, E. Murta, M.H. de Sá. Int. J. Conserv. Sci. 1(1), 47 (2010).

5. I. C. A. Sandu, M. H. de Sá, M. C. Pereira. Surf. Interface Anal. 43, 1134 (2011).

6. E. Emmerling, M. Kühlenthal, M. Richter. Coloured Glazes on Metal Leaf from the Baroque and Rococo Period, (A. Siegl ed.), Munich (2013).

7. V. Beltran, N. Salvadó, S. Butí, G. Cinque. Microchem. J. 118, 115 (2015).

8. F. R. Bartolomé Garcia. La policromía barroca en Álava, (Diputación Foral de Álava. Departamento de Cultura, ed.), Vitoria (2001).

9. N. Salvadó, S. Butí, M.Cotte, G. Cinque, T. Pradell, App. Phys. A 111, 47(2013).

10. E. Pouyet, B. Fayard, M. Salomé, Y. Taniguchi, F. Sette1, M. Cotte. Herit Sci 3(3), 1 (2015).

11. V. Beltran, N. Salvadó, S. Butí, G. Cinque, K. Webbe, T. Pradell. Anal. Chem. 87, 6500 (2015).

12. N. Salvadó, N, S. Butí, M.J. Tobin, E. Pantos, N.W.J. Prag, T. Pradell. Anal. Chem. 77(11), 3444 (2005).

13. Cinque G, Frogley M, Wehbe K (2011) Multimode InfraRed Imaging and Microspectroscopy (MIRIAM) Beamline at Diamond. Synchrotron Radiation News 24(5):24-33

14. Juanhuix J, Gil-Ortiz F, Cuni G et al (2014) Developments in optics and performance at BL13-XALOC, the macromolecular crystallography beamline at the ALBA synchrotron. J. Synchrot. Radiat 21:679-689

15. O. Schalm, A. Crabbé, P. Storme, R. Wiesinger, A. Gambirasi, E. Grieten, P. Tack, S. Bauters, C. Kleber, M. Favaro, D. Schryvers, L. Vincze, H. Terryn, A Patelli. Apply. Phys. A 122, 903 (2016).

16. S. Gialanella, E. Possenti, D. Chateigner, L. Lutterotti, F. Marino. Apply. Phys. A 113, 1001 (2013)

17. G.P. Mastrotheodoros, K.G. Beltsios, Y. Bassiakos, V. Paapadopaulou. Archaeometry DOI: 10.111/arcm.12287 (2017).

18. N. Salvadó, S. Butí, A. Labrador, G. Cinque, H. Emerich, T. Pradell. Anal. Bional. Chem, 399(9), 3041 (2011).

19. H.A. Ankersmit, N.H. Tennent, S.F. Watts. Atmos. Environ. 39, 695 (2005)

20. J. Novakovic, P. Vassiliou. Conservation of Cultural Heritage, pp 58-63 V. Argyropoulus, Athens (2007).

21. G. Marchard, E. Guilminot, S. Lemoine, L. Rosette, M. Vieau, N. Stephant. Heritage Science 2(5) 1 (2014).

22. M. Watanabe, S. Shinozaki, E. Toyoda, K. Asakura, T. Ichino, N. Kuwaki, Y. Higashi, T. Tanaka. Corrosion 62(3) 243 (2006).

23. D. Hraldil, P. Bezdička, J. Hradilová, V. Vašutová. Microchem. J. 125, 10 (2016).

24. D. Hraldil, J. Hradilová, P. Bezdička, S. Švarcová. Appl. Clay Sci. 118, 8 (2015).

25. L. Vaculíková, E. Plevová. Acta Geodyn. Geomater., 2, 2 (138), 167 (2005).

26. M. Singha, L. Singh, Indian J Pure\&Appl Phys, 54, 116 (2016).

27. F. Pacheco, Arte de la Pintura. p.507. Cátedra Madrid (2009).

28. S. Dallongeville, M. Koperska, N. Garnier, G. Reille-Taillefert, C. Rolando, C. Tokarski. Anal Chem 2011,83 (24), 9431(2011).

29. N. Salvadó, S. Butí, T. Pradell, B. Beltran, G. Cinque, J. Juanhuix, L. Font, R. Senserrich. Anal. Methods. 8(7), 1637 (2016). 
30. V Beltran, N Salvadó, S Butí, T Pradell, Anal Bional Chem 408, 4073 (2016).

31. V. Beltran, N. Salvadó, S. Butí, G. Cinque, T. Pradell. J. Nat. Prod. 80, 854 (2017).

32. J Kirby, M Spring, C Higgit, National Gallery Technical Bulletin, 28, 69(2007).

33. J Kirby, M Spring, C Higgit, National Gallery Technical Bulletin, 26, 71(2005).

34. D Cardon, Le monde des teintures naturelles. Chapter 2. Belin, Paris (2003).

35. E. Rosenberg, Anal. Bional. Chem. 391, 33(2008).

36. F Pozzi, M Leona. J. Raman Spectrosc. 47, 67(2015)

37. F Pozzi, S Zaleski, F Casadio, R P Van Duyne, J. Phys. Chem. DOI: 10.1021/acs.jpcc.6b03317

38. R. Woudhuysen-Keller. Aspects of Painting Technique in the Use of Verdigris and Copper Resinate. In Historical Painting Techniques, Materials, and Studio Practice (Arie Wallert, Erma Hermens, Marja Pee, eds.), pp65-69 The Getty Conservation Institute (1995).

39. H. Kühn. Verdigris and copper resinate. In Artists' Pigments: A handbook of their history and characteristics, vol 2, (A. Roy ed.) pp.131-158. Archetype Publications, London (1993).

40. C. Arrabal, M. Cortijo, B.F. De Simón, M.C. García Vallejo, E. Cadahía. Biochem. Syst. Ecol. 33(10), 1007(2005)

41. C. Arrabal, M. Cortijo, B.F. De Simón, M.C. García Vallejo, E. Cadahía. Holzforschung. 56(3), 261(2002)

42. S. Rezzi, A. Bighelli, V. Castola, J. Casanova. Ind Crops Prod. 21(1), 71(2005).

43. V. Mosini, R.Samperi. Phytochemistry. 24(4), 859(1985).

44. N.M. Joye, R.V. Lawrence. J. Chem. Eng. Data. 12(2), 279(1967).

45. R.Gref. For. Pathol. 17(4-5), 227 (1987).

46. A.C. Gören, G. Bilsel, A.H. Oztürk, G.Topçu. Nat. Prod. Commun. 5(11), 1729(2010)

47. S. Sundqvist, E. Paatero, H. Tenhola. Can. J. Chem. Eng. 77(3), 465(1999). 

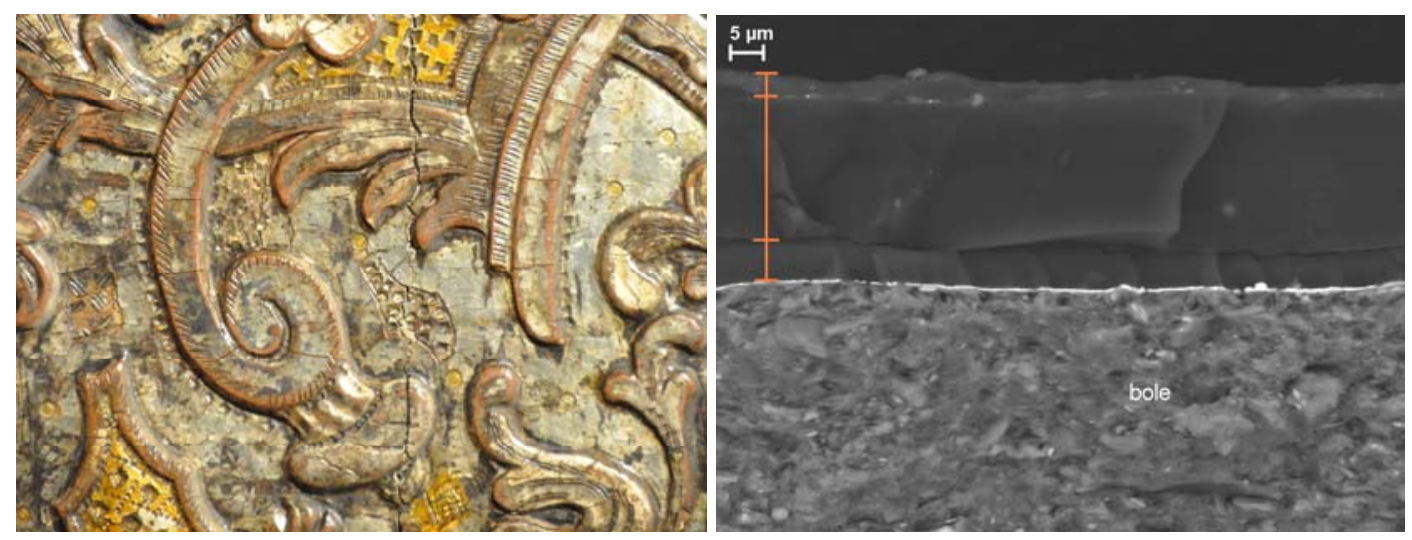

a

\section{b}
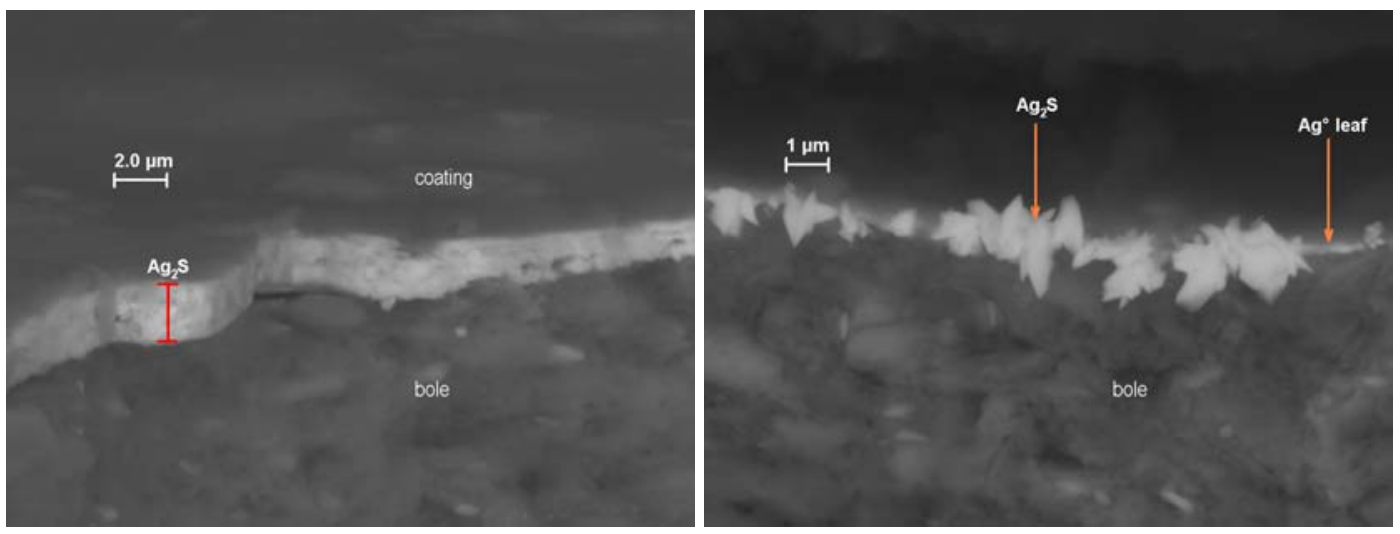

C

d

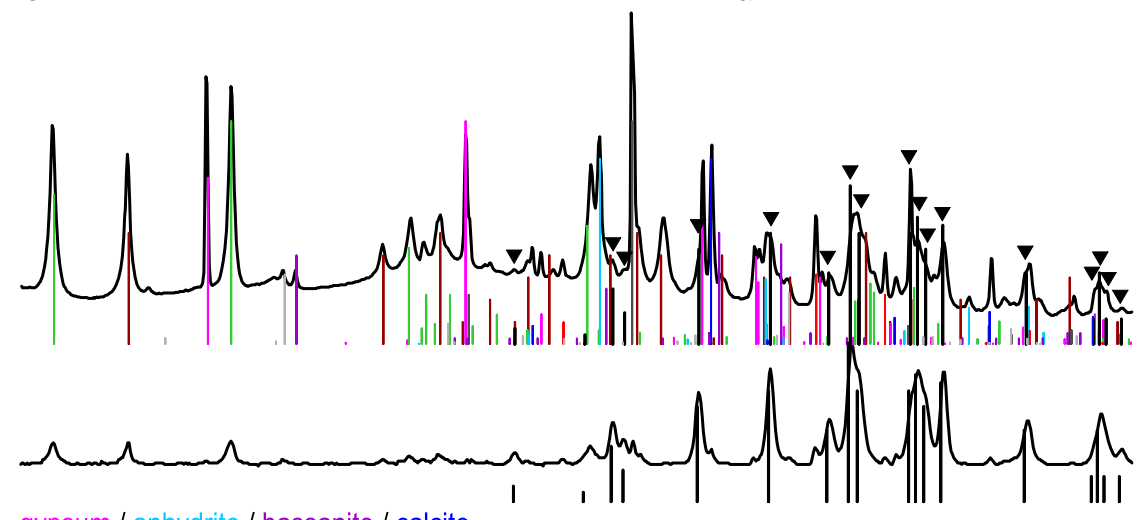

gypsum / anhydrite / bassanite / calcite

vacanthite $\mathrm{Ag}_{2} \mathrm{~S}$

clinochlore / muscovite / hematite / quartz / calcite / weddellite

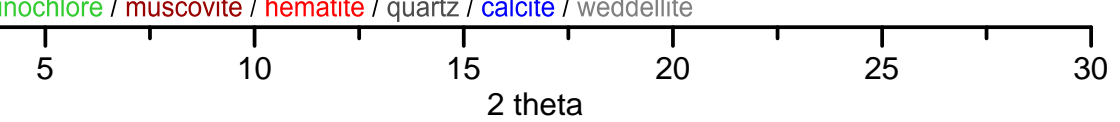

$\mathbf{e}$

\section{Figure 1.}

a) Detail from the Altar frontal of Saint Joachim altarpiece.

SEM-BSE images corresponding to $\mathbf{b})$ layer structure of the yellow luster: acrylic resin, yellow glaze, protein coating, a silver leaf with $\mathrm{Ag}$ and low $\mathrm{Cl}$ content, bole; c) Originally unprotected silver leaf showing high $\mathrm{S}$ and very low $\mathrm{Cl}$ at present coated with an acrylic resin from the 1997 intervention; d) Badly protected silver leaf showing $\mathrm{S}$ and low $\mathrm{Cl}$.

e) $\mu \mathrm{SR}$-XRD patterns from: top, partly lost silver leaf from Saint Rufus altarpiece and bottom, unprotected silver leaf shown in c) 

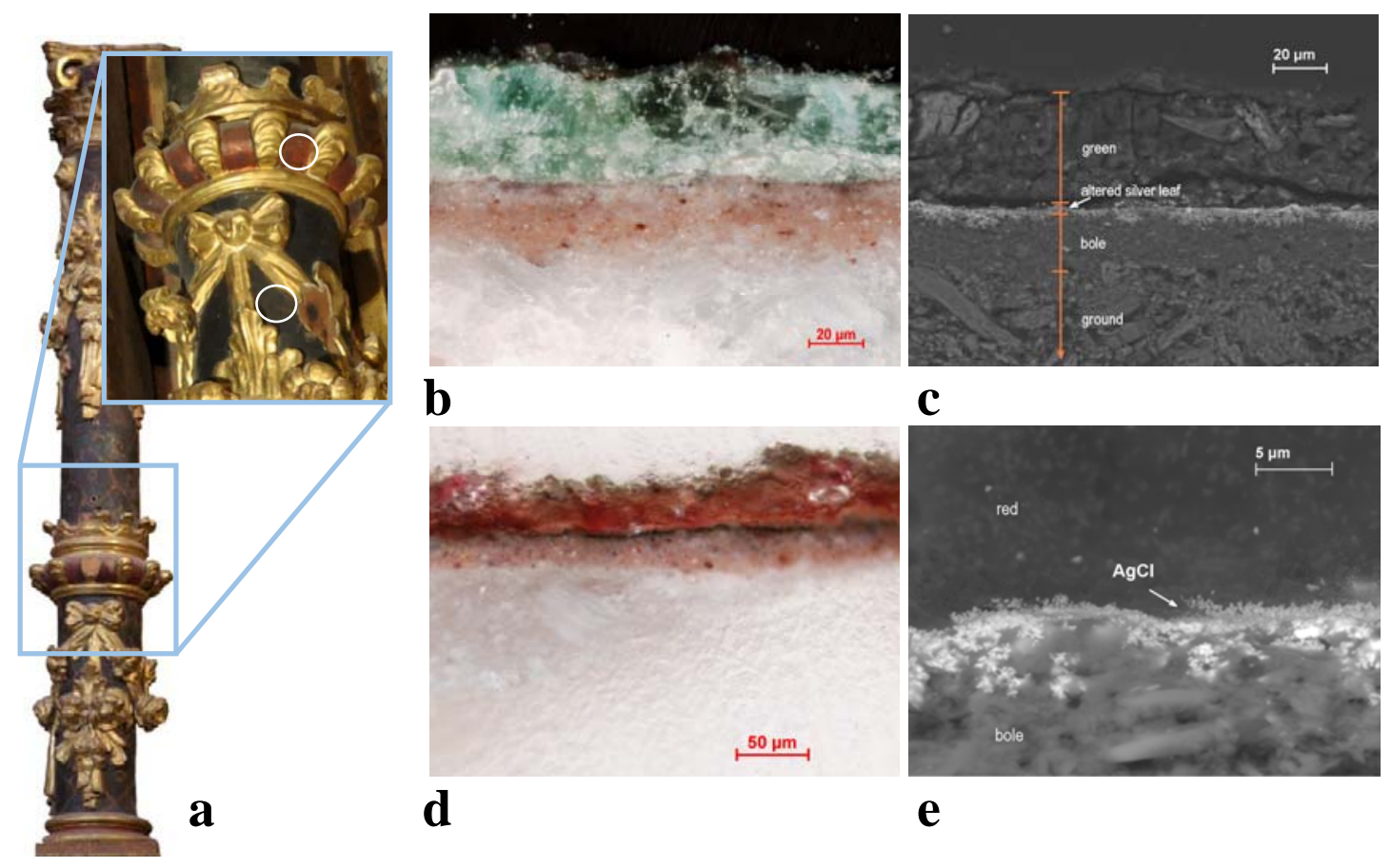

b
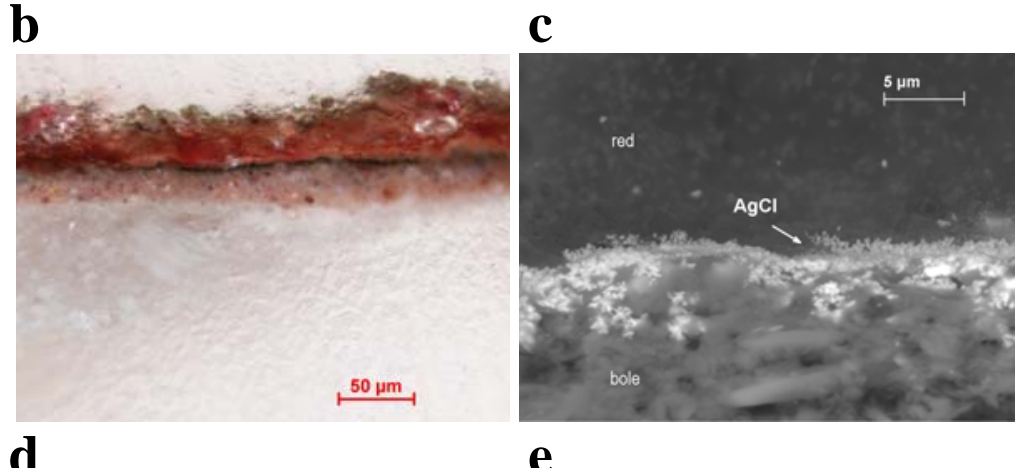

d

$\mathbf{e}$

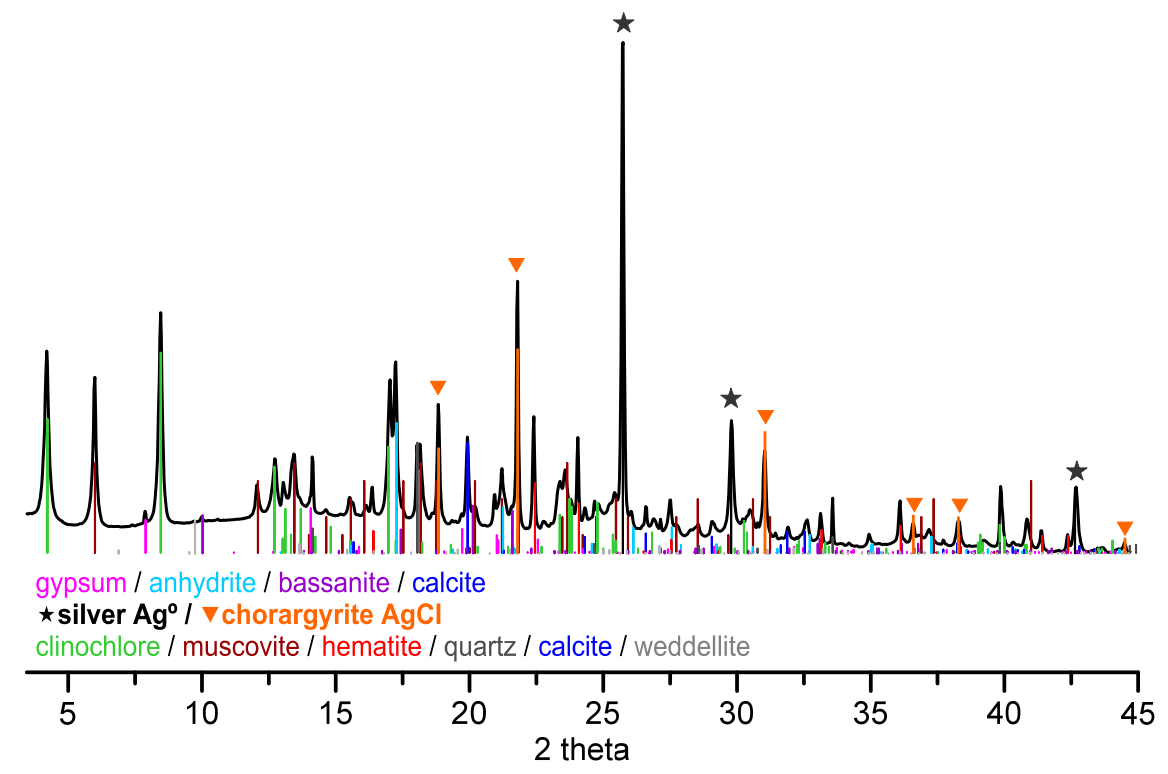

f

Figure 2.

a) Picture from a column and magnification of a detail from Saint Rufus altarpiece. White circles mark the red and green lusters analysed.

b) OM and c) SEM images of a cross section of the green luster.

d) OM and e) SEM images of a cross section of the red luster.

f) $\mu \mathrm{SR}-\mathrm{XRD}$ pattern from the silver leaf protected by the red glazing. 


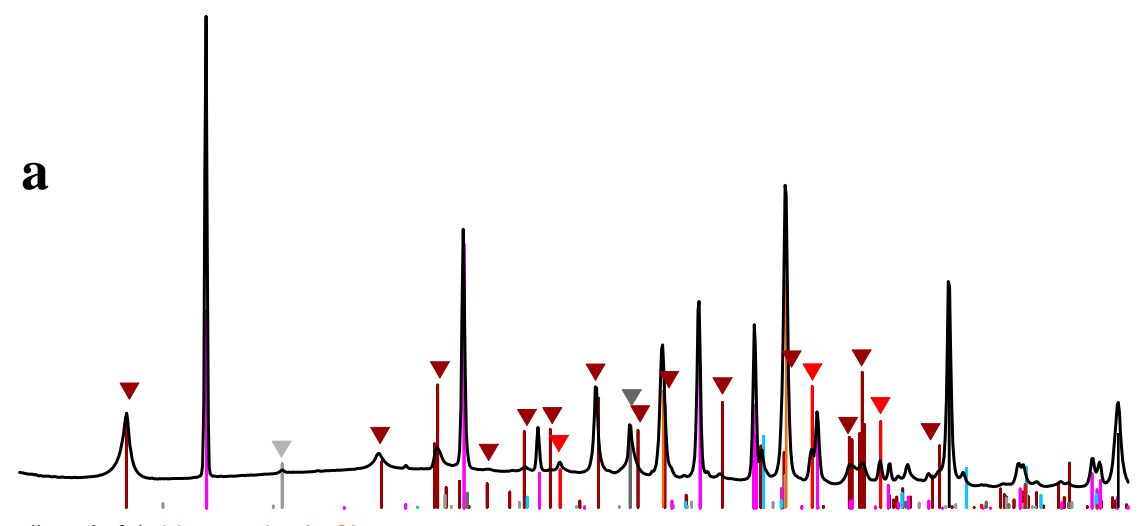

silver $\mathrm{Ag}^{\circ} /$ chlorargyrite $\mathrm{AgCl}$

$\nabla$ muscovite $\mathrm{KAl}_{2} \mathrm{Si}_{3} \mathrm{AlO}_{10}(\mathrm{OH})_{2} / \nabla$ hematite $\mathrm{Fe}_{2} \mathrm{O}_{3} / \nabla$ quartz $\mathrm{SiO}_{2} / \nabla$ weddellite $\mathrm{CaC}_{2} \mathrm{O}_{4} \cdot 2 \mathrm{H}_{2} \mathrm{O}$

gypsum $\mathrm{CaSO}_{4} \cdot 2 \mathrm{H}_{2} \mathrm{O} /$ anhydrite $\mathrm{CaSO}_{4}$

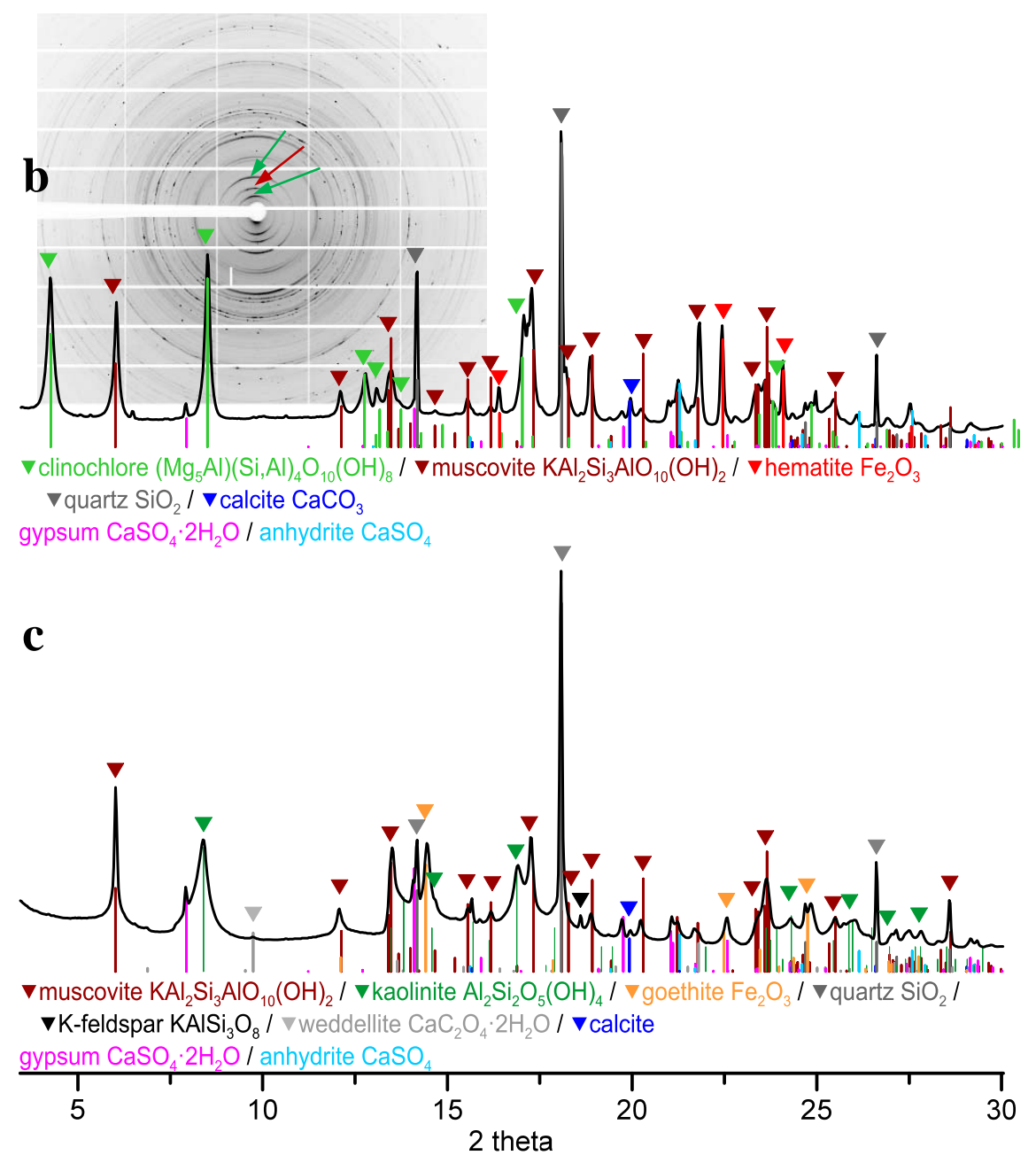

Figure 3. $\mu$ SR-XRD patterns of the three bole layers identified;

a) red bole from All Souls altarpiece (silver and its alteration compounds and ground layer are also determined because the bole layer is only $<10 \mu \mathrm{m}$ thick)

b) red-violet bole from Saint Rufus altarpiece; the inset shows the 2D diffraction pattern showing the clay mineral crystalline planes $(00 \mathrm{n})$ preferentially oriented parallel to the surface; green and dark red arrows indicate the (00n) crystalline planes for clinochlore and muscovite respectively.

c) yellow bole from Our Lady of the Rosary altarpiece. 


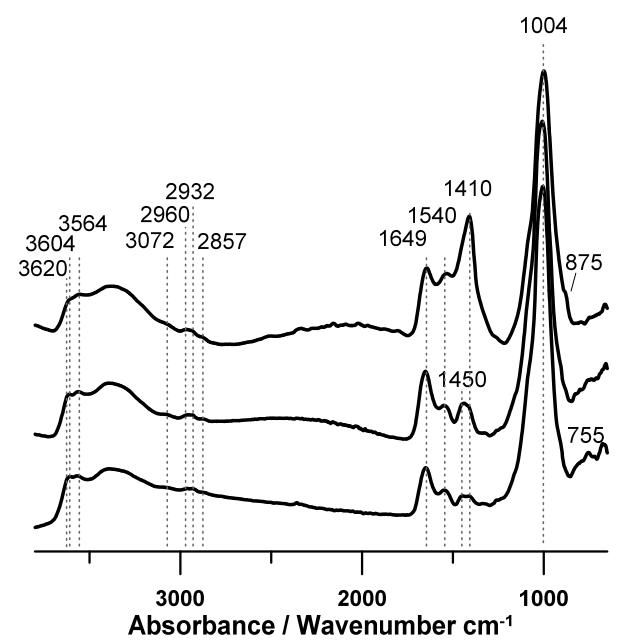

a

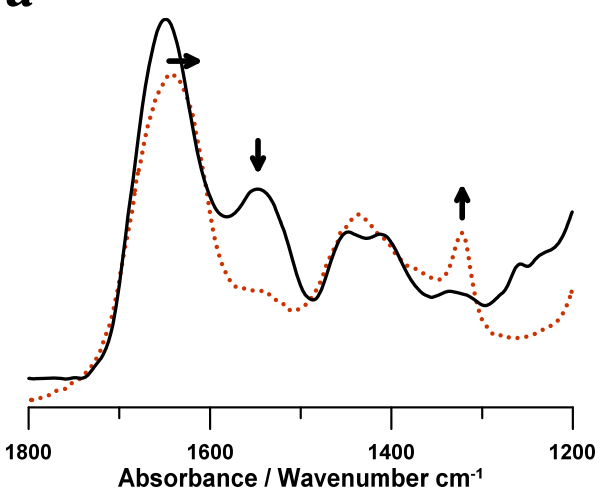

b

Figure 4. a) $\mu$ SR-FTIR spectra from several areas of the red-violet bole layer from Saint Rufus altarpiece showing the heterogeneity of the layer (clay minerals, protein and $1410 \mathrm{~cm}^{-1}$ and $875 \mathrm{~cm}^{-1}$ are related to calcium carbonate).

b) Comparison between the spectra taken from the middle of the bole layer (black solid line) and near to the ground (brown dash line). The protein decreases and calcium oxalate increases in the region near the ground. 


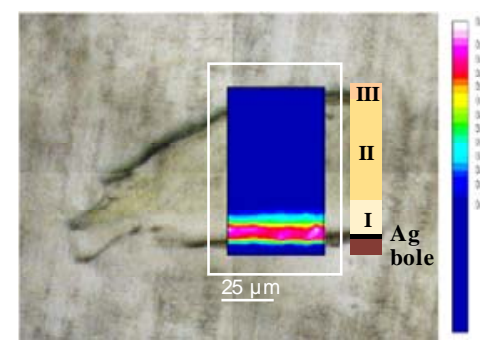

a

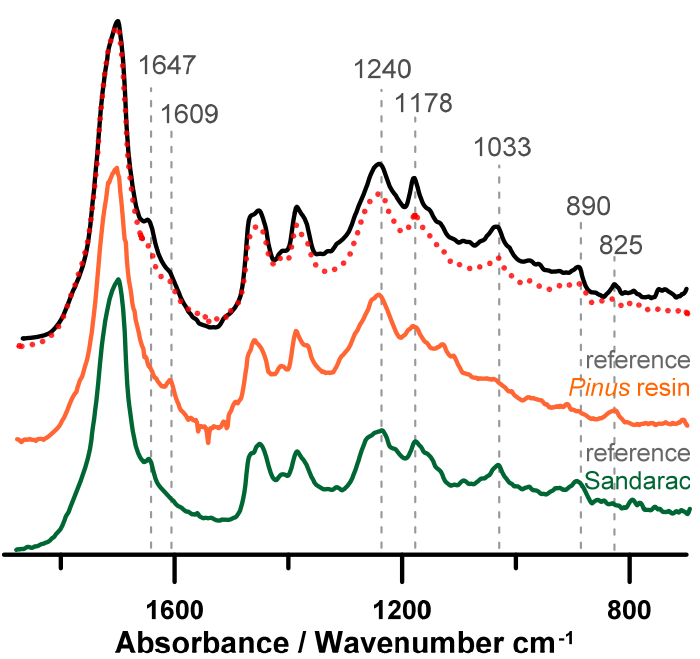

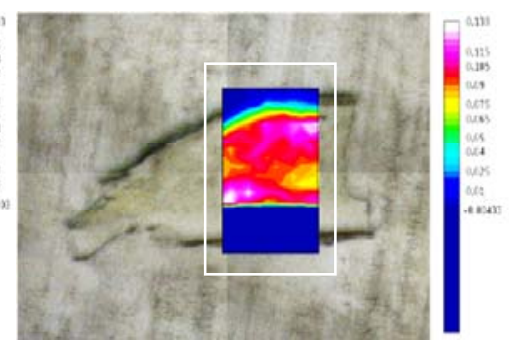

b

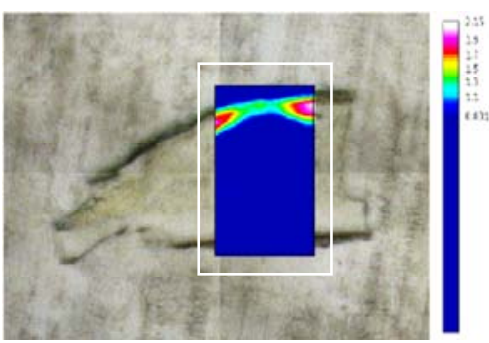

C

d

Figure 5. Thin cross section of the yellow luster from the Altar frontal of Sant Joachim showing a multi-layered structure constituted by bole, silver leaf and three coating layers. Transmission $\mu$ SRFTIR intensity maps of the cross section obtained integrating the bands at:

a) $1543 \mathrm{~cm}^{-1}$, b) $1700 \mathrm{~cm}^{-1}$ and c) $1729 \mathrm{~cm}^{-1}$ corresponding to protein (layer I), yellow glaze (layer II) and acrylic (layer III) respectively.

d) Comparison between the spectrum corresponding to layer II (black line) and those (dashed red line) calculated adding the spectra from aged Pinus nigra Arnold resin dated 1884

(Economic Botany Collection of Kew, ref. 28172, orange line) and sandarac dated 1953

(Economic Botany Collection of Kew, ref. 95431, green line). 

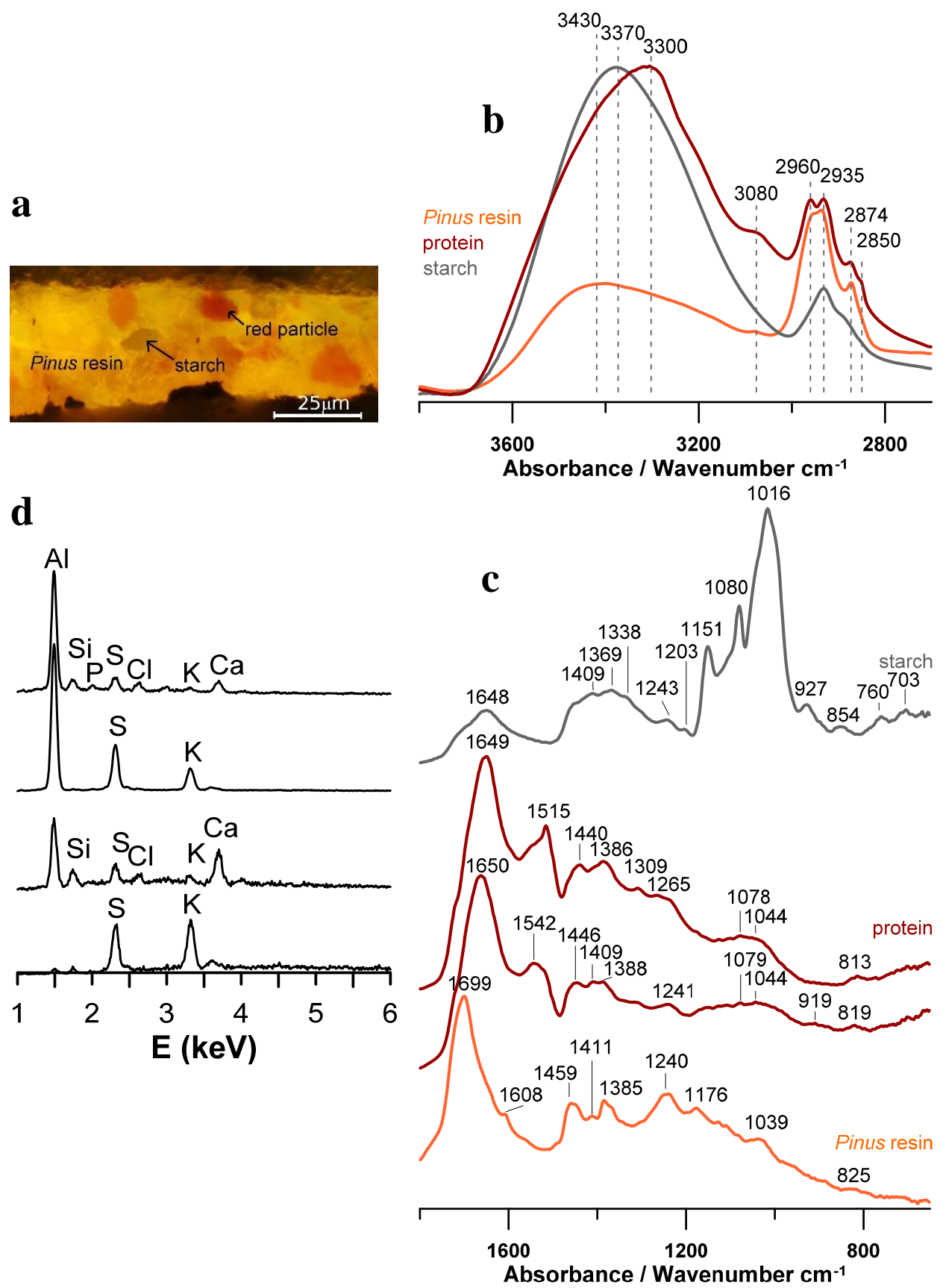

Figure 6. a) Fluorescence optical image of the $25 \mu \mathrm{m}$ thick red glaze from Saint Rufus altarpiece showing the presence of different particles (resin matrix, red lake and starch). b) $3900-2700 \mathrm{~cm}^{-1}$ and c) $1800-650 \mathrm{~cm}^{-1}$ range from the $\mu$ SR-FTIR spectra related to: Protein from the red particles (red line), Pinus resin matrix (orange line) and starch grain (grey line). d) SEM-EDS analysis of several red particles. 


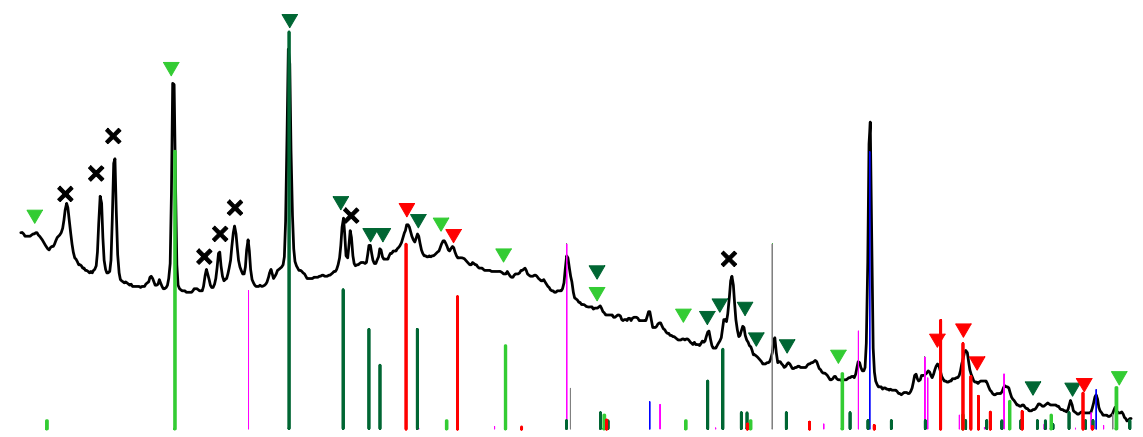

gypsum / calcite / quartz

$\nabla \mathrm{Cu}\left(\mathrm{CH}_{3} \mathrm{COO}\right) \cdot \mathrm{H}_{2} \mathrm{O} / \nabla \mathrm{Cu}\left(\mathrm{CH}_{3} \mathrm{COO}\right)_{2} \cdot\left[\mathrm{Cu}(\mathrm{OH})_{2}\right]_{3} \cdot 2 \mathrm{H}_{2} \mathrm{O} /$ atacamite $\mathrm{Cu}_{2} \mathrm{Cl}(\mathrm{OH})_{3}$

$\mathrm{x}$ - copper reaction compounds

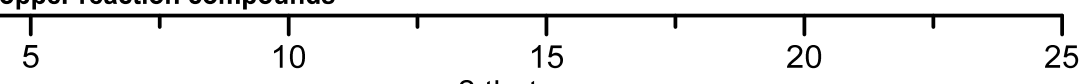

a

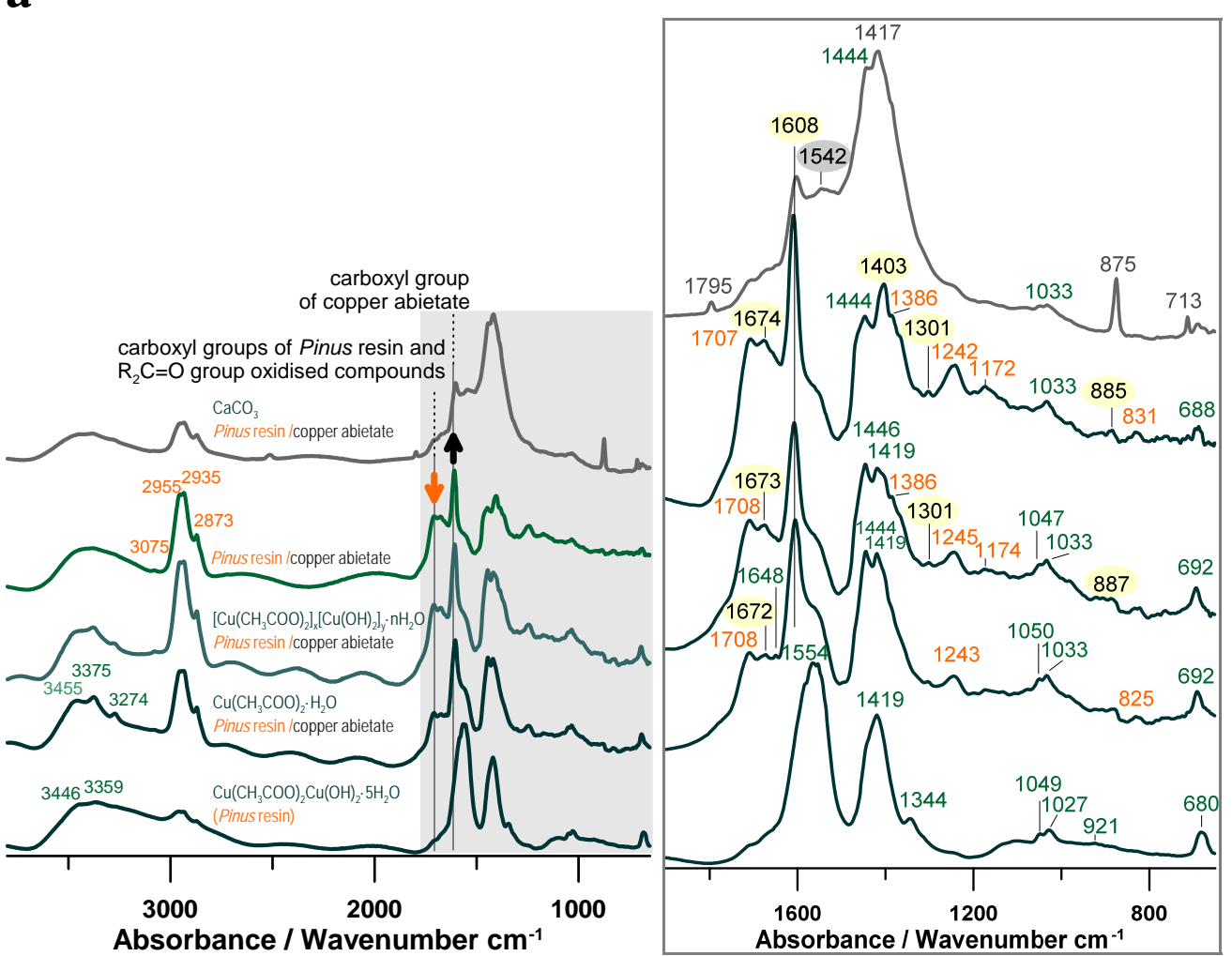

b

Figure 7. Green glaze from Saint Rufus altarpiece.

a) $\mu$ SR-XRD pattern.

b) $\mu$ SR-FTIR spectra. The bands wavenumbers corresponding to the copper pigment, aged Pinus resin and calcium carbonate are marked in green, orange and grey respectively. Other bands related to copper and calcium abietates and pimaranes and discussed in the text are marked in black. 
Table 1. Samples description

\begin{tabular}{|c|c|c|c|c|}
\hline altarpiece & $\begin{array}{c}n^{o} \\
\text { samples }\end{array}$ & glaze & metal & bole \\
\hline \multirow{2}{*}{ All souls } & 1 & orange & \multirow{2}{*}{ silver } & \multirow{2}{*}{ red } \\
\hline & 1 & amber & & \\
\hline \multirow{4}{*}{ Saint Joachim } & 2 & amber & gold & \multirow{4}{*}{ red-violet } \\
\hline & 1 & orange & & \\
\hline & 3 & blue & silver & \\
\hline & 1 & red & & \\
\hline \multirow{3}{*}{$\begin{array}{l}\text { Saint Joachim. } \\
\text { Altar Frontal }\end{array}$} & 2 & - & \multirow{2}{*}{ silver } & \multirow{3}{*}{ red-viole } \\
\hline & 1 & yellow & & \\
\hline & 1 & - & gold & \\
\hline \multirow{7}{*}{ Saint Rufus } & 2 & - & \multirow{3}{*}{ gold } & \multirow{7}{*}{ red-violet } \\
\hline & 1 & amber & & \\
\hline & 1 & red & & \\
\hline & 1 & green & \multirow{4}{*}{ silver } & \\
\hline & 3 & red & & \\
\hline & 1 & - & & \\
\hline & 1 & amber & & \\
\hline \multirow{6}{*}{$\begin{array}{l}\text { Our lady of } \\
\text { the Rosary }\end{array}$} & 1 & amber & \multirow{4}{*}{ silver } & \multirow{6}{*}{ yellow } \\
\hline & 1 & red & & \\
\hline & 1 & green & & \\
\hline & 1 & blue & & \\
\hline & 1 & green & \multirow{2}{*}{ gold } & \\
\hline & 1 & red & & \\
\hline
\end{tabular}

